\title{
Identifying Risk Factors for Central Pontine and Extrapontine Myelinolysis After Liver Transplantation: A Case-Control Study
}

\author{
Isabelle Morard • Yvan Gasche • Mark Kneteman • Christian Toso • \\ Ariane Mentha · Glenda Meeberg • Gilles Mentha • Norman Kneteman • \\ Emiliano Giostra
}

Published online: 14 November 2013

(C) Springer Science+Business Media New York 2013

\begin{abstract}
Background Central pontine and extrapontine myelinolysis (CPEPM) is a rare but potentially fatal complication after orthotopic liver transplantation (OLT). The aim of this study was to identify risk factors for development of CPEPM after OLT and to assess patient outcome.

Methods We reviewed the clinical data of 1,378 patients who underwent OLT between 1987 and 2009 in Geneva, Switzerland and Edmonton, Canada. Nineteen patients (1.4\%) developed CPEPM. We compared their characteristics with
\end{abstract}

Present Address:

I. Morard $(\bowtie)$. E. Giostra

Department of Gastroenterology and Hepatology, Geneva

University Hospital, Rue Gabrielle-Perret-Gentil 4,

1211 Geneva 14, Switzerland

e-mail: isabelle.morard@hcuge.ch

I. Morard - C. Toso - A. Mentha - G. Mentha - E. Giostra Department of Transplantation, Geneva University Hospital, Geneva, Switzerland

Present Address:

Y. Gasche

Division of Critical Care Medicine, Geneva University Hospital,

Rue Gabrielle-Perret-Gentil 4, 1211 Geneva 14, Switzerland

Y. Gasche

Geneva Neuroscience Center, Geneva University, Geneva,

Switzerland

Present Address:

M. Kneteman · G. Meeberg · N. Kneteman

Department of Surgery, University of Alberta, Edmonton, AB,

Canada

Present Address:

C. Toso $\cdot$ A. Mentha $\cdot$ G. Mentha

Department of Visceral Surgery, Geneva University Hospital,

Rue Gabrielle-Perret-Gentil 4, 1211 Geneva 14, Switzerland control patients, matched by age, gender, date of OLT, and MELD score.

Results The 19 patients with CPEPM (7F, mean age $52.1 \pm 2$ years) had a mean MELD score of $26 \pm 2.2$. Before OLT, patients who develop CPEPM presented more frequently low $(<130 \mathrm{mmol} / \mathrm{l} ; p<0.04)$ and very low $(<125 \mathrm{mmol} / \mathrm{l} ; \quad p<0.009)$ sodium than controls. In patients developing CPEPM, the number of platelet units and fresh frozen plasma transfused during surgery was higher ( $p=0.05$ and 0.047), hemorrhagic complications were more frequent after OLT $(p=0.049)$, and variations of sodium before and after OLT were higher $(p=0.023)$. The association of $>2$ of these conditions were strongly associated with CPEPM $(p=0.00015)$. Mortality at 1 year of patients developing CPEPM was higher (63 vs. $13 \%$, $p<0.0001$ ).

Conclusions High MELD score patients undergoing OLT, receiving massive perfusions of Na-rich products, experiencing surgery-related hemorrhagic complication and important fluctuations of $\mathrm{Na}$ are at risk of developing CPEPM. Therefore careful monitoring of natremia in the perioperative period and use of water-free perfusion in case of massive blood-products transfusion are critical points of this patient management.

Keywords Orthotopic liver transplantation - MELD . Neurological complications .

Central pontine and extrapontine myelinolysis .

Hyponatremia · Hemorrhagic complications · Mortality

\section{Introduction}

First described by Adams et al. [1] in 1959 central pontine myelinolysis (CPM) is a symmetrically demyelinating 
lesion of the pons often associated with demyelination of other areas of the central nervous system (extrapontine myelinolysis, EPM; [2]). Occasionally reversible [3] or asymptomatic [3, 4] this disease is often associated with severe neurological symptoms frequently progressing to death or permanent neurological damage. Diagnosis is made through correlation of clinical findings with neuroimaging, mainly magnetic resonance imaging (MRI). Radiologic findings may appear days to weeks after the onset of symptoms and are not always correlated neither to symptoms severity nor to clinical evolution [5, 6]. The exact etiology of CPM remains unclear, but it is supposed that any rapid and important osmotic shifts could induce injury to the endothelial cells resulting in their tight junctions break and the release of myelinotoxic factors that can mediate oligodendroglial injury and dissolution of the myelin sheaths.

The incidence of CPM after orthotopic liver transplant (OLT) varies from 0.29 to $11.4 \%$ in observational studies [6-12] to $28.6 \%$ in autopsy series [13-18]. Liver transplant patients represent the third largest group of CPM (17.4\%), after chronic alcoholic patients (39.4\%) and patients who undergo quick correction of hyponatremia ( $>0.5 \mathrm{mmol} / \mathrm{l} / \mathrm{h} ; 21.5 \%$; [19]), with about $165 \mathrm{docu}-$ mented cases published from 1986 to 2009 [4-12, 14, 2032]. The majority of these publications are case reports and retrospective clinical observational studies without control group.

Hyponatremia or its rapid correction is a recognized cause of CPM but, after OLT, some specific risk factors are suspected such as pre-OLT encephalopathy, previous alcoholism, severe malnutrition and ionic disorders associated with end-stage cirrhosis and the use of diuretics. Perioperative volume of blood products infused [10, 11] and, after OLT, the use of calcineurin inhibitors, CNIs [33, 34] may be a risk factor to develop neurological complications [24, 27, 30].

The aim of this study was to identify risk factors for development of clinically relevant central pontine and EPM (CPEPM) after OLT and to assess patient outcome.

\section{Methods}

\section{Patient Selection}

We retrospectively reviewed the clinical data of 1,378 patients who underwent OLT between July 1987 and December 2009 in the Geneva, Switzerland $(n=523)$ and Edmonton, Canada $(n=855)$ liver transplant programs.

The study was approved by the Ethics Committee of both centers.
CPEPM diagnosis was made on neurological symptoms correlated with brain MRI. Neurological symptoms suggestive of CPEPM were progressive lethargy, flaccid quadriparesis, decreased reflexes, dysarthria, dysphagia, aphasia, ophthalmoplegia, akinesia, pyramidal syndrome, choreoathetosis, catatonia, or ataxia. In association with these symptoms, CPEPM was diagnosed by MRIs showing hyperintense signals on T2-weighted and FLAIR imaging in the central pons, thalamus, basal ganglia, cerebellum and subcortex, without enhancement or mass effect [22, 35]. Increased signals on diffusion-weighted imaging in the same regions were also considered [36]. Patients with other neurological findings such as stroke or absence of typical MRI imaging were excluded.

Nineteen patients were diagnosed as having CPEPM. For each of these patients, we selected two control patients without CPEPM, matched by age \pm 10 years, gender, date of OLT \pm 18 months, MELD score [37] calculated as $(0.957$ $\ln ($ creatinine $)+0.378 \ln ($ bilirubin $)+1.120 \ln ($ international normalized ratio of prothrombin) +0.643$) \times 10(36) \pm$ 5 points, emergency status, and compared their clinical and biochemical parameters before, during, and after OLT.

\section{Risk Factors for CPEPM After OLT}

To determine risk factors for CPEPM after OLT, we compared the CPEPM group $(n=19)$ with the control group ( $n=38$ ) for the following clinical and biochemical parameters.

\section{Pre-operative Clinical Parameters on the Day of OLT}

Gender, body mass index (BMI), indication for OLT, CHILD score at OLT, encephalopathy at OLT graded from 1 to 3 , and ascites at OLT graded from 1 to 3 .

\section{Pre-operative Biochemical Parameters (Just Before OLT)}

Creatinine, INR, bilirubin, albumin, $\mathrm{Hb}$, platelets, white blood cells (WBCs), glucose, $\mathrm{Na}, \mathrm{K}, \mathrm{Mg}$, ASAT, ALAT, GGT, and alkaline phosphatase.

\section{Donor's Data}

Age, gender, and BMI.

\section{Per-operative Clinical Parameters}

Warm and cold ischemia time, number of red blood cells (RBCs), platelet units and fresh frozen plasma (FFP) transfused during surgery, episodes of hypotension defined as 
mean arterial pressure $<60 \mathrm{mmHg}$, and episodes of hypertension defined as mean arterial pressure $>100 \mathrm{mmHg}$.

\section{Post-operative Clinical Parameters}

Delay between OLT and clinical CPEPM onset, cerebral MRI description in case of CPEPM, CPEPM evolution, cause of death and its delay after CPEPM and OLT, day of extubation, immunosuppression (use of steroids and doses, blood levels of tacrolimus, cyclosporine, rapamune, everolimus), immunosuppression switch after diagnosis of CPEPM, hemorrhage after OLT requiring transfusion or surgery, post-OLT metabolic acidosis $(\mathrm{pH}<7.39$ and normal $p_{\mathrm{CO}_{2}}$ ), post-OLT hypoxemia (arterial $p_{\mathrm{O}_{2}}<8 \mathrm{kPa}$ on ABG while in ICU), post-OLT hypercapnia (arterial $p_{\mathrm{CO}_{2}}>6 \mathrm{kPa}$ on $\mathrm{ABG}$ while in ICU), and occurrence of rejection, treatment of rejection and its delay before CPEPM.

\section{Post-operative Biochemical Parameters}

Highest value between OLT and clinical CPEPM or highest value during the 15 days following OLT for the controls: Na, K, osmolality, AST, ALT, WBC, creatinine and CNI and $\mathrm{m}$-TOR inhibitors trough levels.

Lowest value between OLT and clinical CPEPM or lowest value during the 15 days following OLT for the controls: $\mathrm{Hb}$, platelets, albumin, glucose, $\mathrm{Na}$, and $\mathrm{Mg}$.

\section{Statistical Analysis}

Numerical data are expressed as percentage (\%), mean with standard deviation (SD) or median with range, as appropriate. Quantitative variables were compared using Student $t$ test or Mann-Whitney test as needed. Pearson $\chi^{2}$ or Fisher exact test was used for qualitative parameters. Survival rates were evaluated using Kaplan-Meier curves and logrank test. Values of $p<0.05$ were considered statistically significant. Data analysis was performed using the SPSS statistical software version 20.0 (IBM SPSS Statistics).

\section{Results}

Out of 1,378 patients who underwent OLT from 1987 to 2009, $19(1.4 \%)$ developed clinical CPEPM. There were 7 women and 12 men, with a mean age of $52.1 \pm 2$ years, a mean MELD score of $26 \pm 2.2$, and a median MELD score of 24 (11-40), a median CHILD score of 13 (10-14). Indications for OLT were: alcoholic cirrhosis in 9 patients $(47 \%)$, HCV cirrhosis in $4(21 \%)$, primary biliary cirrhosis (PBC) in $2(10.5 \%)$, fulminant hepatitis in $1(5 \%)$, and other causes of cirrhosis in 3 ( $1 \mathrm{HBV}$ cirrhosis, 1 idiopathic cirrhosis and 1 AIAD; $16.5 \%)$. Two of these patients had a hepatocellular carcinoma, HCC (Table 1).

Pre-operative Clinical and Biochemical Parameters

Patients and controls were similar in terms of pre-operative clinical and biochemical parameters. INR values tended to be higher in patients who developed CPEPM after OLT $(p=0.059)$. Patients who developed CPEPM presented more frequently low $(<130 \mathrm{mmol} / \mathrm{l} ; 47.4$ vs. $21 \%$, $p<0.04)$ and very low $(<125 \mathrm{mmol} / \mathrm{l} ; 26.3$ vs. $0 \%$, $p<0.009$ ) plasma sodium than controls (Table 2).

\section{Donors Parameters}

Donors parameters such as BMI $(25.3 \pm 1.2$ vs. $24.6 \pm$ $\left.0.8 \mathrm{~kg} / \mathrm{m}^{2}\right)$ and age $(48 \pm 5.5$ vs. $45.1 \pm 3$ years $)$ were similar.

\section{Per-operative Clinical Parameters}

Per-operative clinical parameters showed that warm and cold ischemia time, episodes of hypertension (mean arterial pressure $>100 \mathrm{mmHg}$ ), and episodes of hypotension (mean arterial pressure $<60 \mathrm{mmHg}$ ) did not differ between the two groups. The number of platelet units and FFP transfused during surgery was significantly higher in patients who developed CPEPM $(8.3 \pm 6$ vs. $4 \pm 0.8$, $p=0.05$, and $19.5 \pm 5$ vs. $10.6 \pm 1.4, p=0.047)$. The number of RBCs units was higher in patients with CPEPM but did not reach statistical significance (Table 3).

Table 1 Cases and controls characteristics

\begin{tabular}{llll}
\hline & Cases & Controls & $p$ \\
\hline Geneva $(n)$ & 7 & 14 & \\
Edmonton $(n)$ & 12 & 24 & \\
Total $(n)$ & 19 & 38 & \\
Gender F/M & $7 / 12(37 \%)$ & $13 / 25(34 \%)$ & 0.844 \\
Age at CPM mean (years) & $52.1 \pm 2$ & $52.6 \pm 1.2$ & 0.827 \\
MELD mean \pm SD & $26 \pm 2.2$ & $25.6 \pm 1.3$ & 0.872 \\
Median (range) & $24(11-40)$ & $24.5(11-41)$ & \\
CHILD median (range) & $13(10-14)$ & $12(8-15)$ & \\
OLT indications & $9(47 \%)$ & $14(37 \%)$ & 0.856 \\
OH & $4(21 \%)$ & $9(24 \%)$ & \\
HCV & $2(10.5 \%)$ & $6(16 \%)$ & \\
PBC & $1(5 \%)$ & $2(5 \%)$ & \\
Fulminant hepatitis & $3(16.5 \%)$ & $7(18 \%)$ & \\
Others & 2 & 4 & \\
HCC & & & \\
\hline
\end{tabular}


Table 2 Pre-operative clinical and biochemical parameters

\begin{tabular}{llll}
\hline Mean $\pm \mathrm{SD}$ & Cases & Controls & $p$ \\
\hline INR & $2.86 \pm 0.6$ & $1.91 \pm 0.14$ & 0.059 \\
Creatinine $(\mathrm{mmol} / \mathrm{l})$ & $132 \pm 16$ & $135 \pm 12.5$ & 0.829 \\
Bilirubin $(\mathrm{mmol} / \mathrm{l})$ & $264.3 \pm 61.6$ & $276.2 \pm 44$ & 0.710 \\
Albumin $(\mathrm{g} / \mathrm{l})$ & $28.2 \pm 1.5$ & $31.1 \pm 1.2$ & 0.140 \\
Hemoglobin $(\mathrm{g} / \mathrm{l})$ & $95.4 \pm 4.4$ & $96.3 \pm 3.7$ & 0.493 \\
Platelets $(\mathrm{U} / \mathrm{ml})$ & $55.8 \pm 5$ & $66.8 \pm 4$ & 0.223 \\
Glucose $(\mathrm{mmol} / \mathrm{l})$ & $8.9 \pm 2.4$ & $6.3 \pm 0.3$ & 0.933 \\
Sodium $(\mathrm{mmol} / \mathrm{l})$ & $133 \pm 2.2$ & $134.8 \pm 0.9$ & 0.623 \\
Na $<130 \mathrm{mmol} / \mathrm{l}, n(\%)$ & $9(47.4)$ & $8(21)$ & 0.04 \\
Na <125 mmol/l, $n(\%)$ & $5(26.3)$ & 0 & 0.009 \\
Potassium $(\mathrm{mmol} / \mathrm{l})$ & $4.17 \pm 0.1$ & $4.4 \pm 0.13$ & 0.154 \\
Magnesium $(\mathrm{mmol} / \mathrm{l})$ & $0.71 \pm 0.06$ & $0.8 \pm 0.07$ & 0.360 \\
AST $(\mathrm{IU} / \mathrm{l})$ & $94.7 \pm 28$ & $113 \pm 44$ & 0.393 \\
ALT $(\mathrm{IU} / \mathrm{l})$ & $159 \pm 37$ & $162 \pm 52$ & 0.332 \\
Ascites $1 / 2 / 3^{\mathrm{a}}$ & $1 / 9 / 9$ & $6 / 11 / 21$ & 0.284 \\
Encephalopathy ${ }^{\mathrm{b}}$ 0/1-2/3-4 & $1 / 9 / 9$ & $6 / 16 / 16$ & 0.521 \\
BMI $\left(\mathrm{kg} / \mathrm{m}^{2}\right)$ & $25.3 \pm 1.2$ & $24.6 \pm 0.8$ & 0.733 \\
\hline
\end{tabular}

a According to CHILD score

b According to New Haven score

Table 3 Perioperative parameters

\begin{tabular}{llll}
\hline Mean $\pm \mathrm{SD}$ & Cases & Controls & $p$ \\
\hline $\begin{array}{l}\text { Hypotension (TAM <60 mmHg) } \\
(\%)\end{array}$ & 53 & 37 & 0.336 \\
$\begin{array}{l}\text { Hypertension (TAM >100 mmHg) } \\
\quad \%)\end{array}$ & 12.5 & 30.5 & 0.145 \\
Cold ischemia time (min) & $488.6 \pm 45$ & $483.8 \pm 24$ & 0.463 \\
Warm ischemia time (min) & $57.4 \pm 4$ & $56 \pm 2$ & 0.802 \\
Red blood cells (units) & $14 \pm 4$ & $8 \pm 1.2$ & 0.08 \\
Fresh frozen plasma (units) & $19 \pm 5$ & $10.6 \pm 1.4$ & 0.047 \\
Thrombapheresis (units) & $8.3 \pm 6$ & $4 \pm 0.8$ & 0.05 \\
\hline
\end{tabular}

Post-operative Clinical Parameters

Six of the 19 patients with CPEPM remained intubated 230 days after the first neurocognitive impairment. Cyclosporine was used in 12 patients $(63 \%)$ who developed CPEPM and in $42 \%$ of controls (ns). Tacrolimus was used in $37 \%$ of patients who developed CPEPM and in $53 \%$ of controls (ns). Steroids were used in $79 \%$ of patients of both groups. Hemorrhagic complications requiring transfusion or surgery occurred in $32 \%(6 / 19)$ of patients who developed CPEPM and in $10.5 \%$ (4/38) of controls $(p=0.049)$. Metabolic acidosis $(\mathrm{pH}<7.39$ and normal $p_{\mathrm{CO}_{2}}$ ), hypoxemia (arterial $p_{\mathrm{O}_{2}}<8 \mathrm{kPa}$ on $\mathrm{ABG}$ while in
ICU), and hypercapnia (arterial $p_{\mathrm{CO}_{2}}>6 \mathrm{kPa}$ on $\mathrm{ABG}$ while in ICU) did not differ between the two groups after OLT (Table 4). Episodes of rejection did not play any role in the etiology of CPEPM as the majority of them occurred usually after the apparition of neurological symptoms.

\section{Post-operative Biochemical Parameters}

The percentage of patients with high CNI trough levels (cyclosporinemia $>300 \mu \mathrm{g} / \mathrm{l}$ and tacrolimus trough levels $>15 \mu \mathrm{g} / \mathrm{l}$ ) was similar in both groups (58 vs. $50 \%$ : ns). The variations of $\mathrm{Na}$ before and in the first days after OLT were higher in patients with CPEPM than in controls $(15.9 \pm 1.9$ vs. $11.1 \pm 0.9 \mathrm{mmol} / \mathrm{l}, p=0.023)$. Patients with CPEPM tended to undergo quicker correction ( $\geq 0.5 \mathrm{mmol} / \mathrm{l} / \mathrm{h}$ ) of hyponatremia during the first $24 \mathrm{~h}$ after OLT (7/19: $36.8 \%$ vs. 6/38: $15.8 \%, p=0.07)$. The peak values of osmolarity, potassium, AST, ALT, creatinine, and WBC after OLT were similar in both groups. The lowest value of $\mathrm{Hb}$, platelets, albumin, glucose, $\mathrm{Na}, \mathrm{Mg}$ between OLT and clinical CPEPM or lowest value during the 15 days following OLT for the controls was similar in both groups (Table 4).

Post-operative Clinical and Radiological Parameters

The neurological manifestations of CPEPM occurred in $9.53 \pm 6.56$ days after OLT, the earliest 3 days after and the latest 25 days after OLT. Brain imaging was performed within a median of 6 days (1-33) after the first symptoms. MRI features of patients with suspected CPEPM are detailed in Table 5. Majority of patients show pontine and extrapontine lesions on T2/FLAIR. Eleven patients (58 \%) were switched to m-TOR inhibitors after CPEPM, CNI levels were reduced for the other eight patients. Mortality at 1 year of patients developing CPEPM was significantly increased (63 vs. $13 \%, p<0.0001$; Fig. 1).

\section{Risk Factors of Developing CPEPM}

Severe and very severe hyponatremia, transfusion of $\geq 4$ platelet units (median of platelet units transfused in patients with CPEPM), of $\geq 12$ FFP (median of FFP transfused in patients with CPEPM), hemorrhagic complications and increasing of $\mathrm{Na} \geq 12 \mathrm{mmol}$ (median of $\mathrm{Na}$ variation after OLT in patients with CPEPM) in the post-operative course were identified as risk factors for developing CPEPM. Only $8 \%(3 / 38)$ of the controls presented $>2$ of these risks compared with $50.65 \%(10 / 19)$ of patients with CPEPM. The association of $\geq 3$ of these risk factors was strongly associated with CPEPM occurrence $(p=0.00015)$. 
Table 4 Post-operative parameters

${ }^{\text {a }}$ Highest value between OLT and clinical CPEPM or highest value during the 15 days following OLT for the controls

\begin{tabular}{llll}
\hline & Cases & Controls & $p$ \\
\hline Immunosuppression & & & 0.245 \\
Tacrolimus, $n(\%)$ & $7(37)$ & $20(53)$ & \\
Cyclosporine, $n(\%)$ & $12(63)$ & $16(42)$ & \\
Sirolimus, $n$ & & 1 & \\
No immunosuppression, $n$ & & 1 & \\
Hemorrhagic complications, $n(\%)$ & $6(32)$ & $4(10.5)$ & 0.049 \\
Acidosis $\left(\mathrm{pH}<7.39\right.$ and normal $\left.p_{\mathrm{CO}_{2}}\right), n(\%)$ & $7(36)$ & $15(39.5)$ & 0.905 \\
Hypoxemia (arterial $\left.p_{\mathrm{O}_{2}}<8 \mathrm{kPa}\right), n(\%)$ & $7(36)$ & $8(21.6)$ & 0.302 \\
Hypercapnia (arterial $\left.p_{\mathrm{CO}}>6 \mathrm{kPa}\right), n(\%)$ & $6(31)$ & $8(21.6)$ & 0.524 \\
Na changes $>0.5$ mmol/h in the first $24 \mathrm{~h}$ after OLT, $n(\%)$ & $7(36.8)$ & $6(15.8)$ & 0.07 \\
Na changes before-after OLT $(\mathrm{mmol} / \mathrm{l})$, mean $\pm \mathrm{SD}$ & $15.9 \pm 1.9$ & $11.1 \pm 0.9$ & 0.023 \\
Peak ALAT value after OLT $(\mathrm{mmol} / \mathrm{l})$, mean $\pm \mathrm{SD}$ & $848.5 \pm 164.4$ & $1,061.2 \pm 175.4$ & 0.617 \\
Peak ASAT value after OLT $(\mathrm{UI} / \mathrm{l})$, mean $\pm \mathrm{SD}$ & $1,157.7 \pm 191.6$ & $1,469 \pm 200.6$ & 0.488 \\
Peak osmolarity value after OLT, mean $\pm \mathrm{SD}$ & $314.2 \pm 7$ & $308 \pm 4$ & 0.357 \\
CNI trough levels: FK $>15$ or CyA $>300 \mu \mathrm{mol} / \mathrm{l}(\%)$ & 58 & 50 & 0.851 \\
\hline
\end{tabular}

\section{Discussion}

Our study, the largest published till date, using homogenous control population including patients with similar age, gender, MELD score, and date of transplantation, shows that CPEPM after OLT results of an addition of risk factors leading to important shifts in plasma sodium concentration in the first days after surgery. Our data confirm that severe hyponatremia at the moment of transplantation and important peri-operative serum $\mathrm{Na}$ variation are risk factors of developing CPEPM and reveal the role played by the number of FFP units and thrombapheresis transfused during surgery and by post-operative hemorrhagic complications requiring transfusion or surgery. The addition of more than two of these conditions was strongly associated with CPEPM occurrence. Pre-operative INR values tend to be higher in patients who develop CPEPM and may have increased the risk of surgery-related hemorrhagic complications and massive transfusion. This confirms the conclusion of Lee et al. [11] that the use of massive transfusion and volume replacement during surgery may favor the occurrence of CPM. Thrombapheresis, FFP and RBC units are rich in sodium and cause rapid serum sodium shift.

In the present report, patients with CPEPM had significantly greater and tended to have quicker $(\geq 0.5 \mathrm{mmol} / \mathrm{l} / \mathrm{h}$ in the first $24 \mathrm{~h}$ ) sodium fluctuation after OLT. We failed to demonstrate that quick $\mathrm{Na}$ correction occurred only in the first $24 \mathrm{~h}$ after OLT probably because more than one-third of the patients who developed CPEPM underwent reoperation and/or transfusions after transplantation causing $\mathrm{Na}$ fluctuation later in the post-transplantation course.

There was a significantly larger percentage of patients with severe $(<130 \mathrm{mmol} / \mathrm{l})$ and very severe $(<125 \mathrm{mmol} / \mathrm{l})$ hyponatremia in the group with CPEPM as compared with the patients without CPEPM despite the fact that the mean pre-operative plasma sodium concentrations were similar in case and control groups. CPEPM may occur in patients with relatively normal serum sodium: in presence of an osmotic challenge, neuroglia activate energy-dependant cell surface pumps (e.g., Na-K ATPase) to rapidly counteract the electrolyte derangement. In patients with liver failure or in case of malnutrition, it is postulated that glia cells may inherently lack a plentiful supply of glucose or glycogen, hence relatively minor osmotic derangements might lead to a rapid depletion of cellular energy supply and cell death [38, 39]. A lack of adequate concentrations of organic osmolytes predisposes the brain to osmotic injury [40].

Hyponatremia is a common complication of advanced cirrhosis mainly related to impairment in the renal capacity to eliminate solute-free water causing a reduction in serum sodium concentration and hypo-osmolality. This dilutional hyponatremia reflects hemodynamical dysfunction associated with severe portal hypertension [41]. In addition, the use of diuretics in patients with hypervolemic hyponatremia is another cause of hyponatremia in this population of patients with advanced cirrhosis. According to the increased risk of developing CPEPM in case of severe hyponatremia before OLT, diuretics should be used with caution in patients with plasma sodium $\leq 130 \mathrm{mmol} / \mathrm{l}$. Albumin perfusion rich in sodium and known to inhibit antidiuretic hormone should be encouraged before OLT and more effective treatment of dilutional hyponatremia such as vaptan should be studied in patients on waiting list. Peri-operative management of patients undergoing liver transplantation should include careful monitoring of sodium plasma concentration and preference of water-free perfusion in case of massive transfusion of blood products. 
Table 5 MRI features of patients with suspected CPEPM

\begin{tabular}{|c|c|c|c|c|c|c|c|c|c|}
\hline \multirow[t]{2}{*}{ Patients } & \multirow{2}{*}{$\begin{array}{l}\text { Time of } \\
\text { symptoms } \\
\text { after OLT } \\
\text { (days) }\end{array}$} & \multirow[t]{2}{*}{ Type of symptoms } & \multirow{2}{*}{$\begin{array}{l}\text { Time of } \\
\text { MRI after } \\
\text { OLT } \\
\text { (days) }\end{array}$} & \multicolumn{3}{|c|}{ MRI features } & \multirow{2}{*}{$\begin{array}{l}\text { Pontine- } \\
\text { brain } \\
\text { stem } \\
\text { lesions }\end{array}$} & \multirow{2}{*}{$\begin{array}{l}\text { Extrapontine- } \\
\text { brain stem } \\
\text { lesions }\end{array}$} & \multirow[t]{2}{*}{ Outcomes } \\
\hline & & & & $\mathrm{T} 1$ & $\begin{array}{l}\text { T2/ } \\
\text { FLAIR }\end{array}$ & DWI & & & \\
\hline 1 & 8 & $\begin{array}{l}\text { Complete aphasia } \\
\text { Flaccid tetraparesia }\end{array}$ & 14,17 & - & + & - & No & Yes & $\begin{array}{l}\text { Speaking improvement } \\
\text { Death at } 4 \text { months recurrent } \\
\text { disease }\end{array}$ \\
\hline 2 & 23 & Altered consciousness & 51 & - & ++ & - & Yes & Yes & $\begin{array}{l}\text { Death at } 2 \text { months multisystem } \\
\text { failure }\end{array}$ \\
\hline 3 & 5 & Dysarthria, dysphagia & 8,18 & & & & & & $\begin{array}{l}\text { Able to speak } 1 \text { week later, by } \\
4 \text { months able to be up with } \\
\text { walker and discharged from } \\
\text { hospital } \\
\text { Death at } 8 \text { years sepsis }\end{array}$ \\
\hline 4 & 6 & Locked in syndrome & 7 & - & +++ & - & Yes & Yes & $\begin{array}{l}\text { Understand verbal communication, } \\
\text { quadriplegia } \\
\text { Death at } 4 \text { months sepsis, } \\
\text { multisystem failure }\end{array}$ \\
\hline 5 & 3 & Seizure & 16 & - & ++ & - & Yes & No & Alive \\
\hline 6 & 7 & Coma, seizure & 7,18 & + & +++ & - & Yes & Yes & $\begin{array}{l}\text { No significant clinical } \\
\text { improvement } \\
\text { Death at } 4 \text { months treatment } \\
\text { withdrawal }\end{array}$ \\
\hline 7 & 6 & $\begin{array}{l}\text { Respiratory failure, } \\
\text { coma }\end{array}$ & 20 & - & ++ & - & Yes & Yes & $\begin{array}{l}\text { Clinical improvement, extubation, } \\
\text { remained confused } \\
\text { Death at } 2 \text { months cardiovascular }\end{array}$ \\
\hline 8 & 5 & Confusion & 34 & - & +++ & - & Yes & No & $\begin{array}{l}\text { No significant clinical } \\
\text { improvement } \\
\text { Death at } 3 \text { months subarachnoid } \\
\text { hemorrhage }\end{array}$ \\
\hline 9 & 6 & Seizure, coma & 12 & - & + & + & Yes & Yes & $\begin{array}{l}\text { Waked up at } 5 \text { weeks, walked at } \\
7 \text { weeks, discharged from } \\
\text { hospital at } 5 \text { month } \\
\text { Alive }\end{array}$ \\
\hline 10 & 16 & Dysarthria & 19 & - & + & - & Yes & No & Alive \\
\hline 11 & 12 & Altered consciousness & 18 & - & +++ & + & Yes & Yes & $\begin{array}{l}\text { Tracheotomy, persistent seizure } \\
\text { despite treatment, open eyes } \\
\text { Death at } 9 \text { months malignancy }\end{array}$ \\
\hline 12 & 17 & Hand and arm tremor & 17 & - & ++ & + & Yes & Yes & $\begin{array}{l}\text { Death at } 7 \text { months pulmonary } \\
\text { disease }\end{array}$ \\
\hline 13 & 4 & Aphasia, tetraparesia & 9,23 & - & ++ & + & Yes & Yes & $\begin{array}{l}\text { No significant clinical } \\
\text { improvement } \\
\text { Death at day } 46 \text { respiratory arrest } \\
\text { on obstruction of the canula }\end{array}$ \\
\hline 14 & 5 & $\begin{array}{l}\text { Seizure, flaccid } \\
\text { tetraparesia }\end{array}$ & 10 & - & ++ & ++ & Yes & No & $\begin{array}{l}\text { Coma } \\
\text { Death at day } 16\end{array}$ \\
\hline 15 & 7 & Seizure & 11,20 & - & +++ & - & Yes & No & $\begin{array}{l}\text { Persistent dysarthria, psycho-motor } \\
\text { slowering } \\
\text { Death at month } 4 \text { chronic rejection }\end{array}$ \\
\hline 16 & 9 & $\begin{array}{l}\text { Coma, left } \\
\text { extrapyramidal } \\
\text { syndrome, right } \\
\text { pyramidal syndrome }\end{array}$ & 15,53 & - & +++ & + & Yes & Yes & $\begin{array}{l}\text { Persistent dysarthria, psycho-motor } \\
\text { slowering, dependent for } \\
\text { everyday life } \\
\text { Death at month } 11 \mathrm{HCV} \text { recurrence }\end{array}$ \\
\hline
\end{tabular}


Table 5 continued

\begin{tabular}{|c|c|c|c|c|c|c|c|c|c|}
\hline \multirow[t]{2}{*}{ Patients } & \multirow{2}{*}{$\begin{array}{l}\text { Time of } \\
\text { symptoms } \\
\text { after OLT } \\
\text { (days) }\end{array}$} & \multirow[t]{2}{*}{ Type of symptoms } & \multirow{2}{*}{$\begin{array}{l}\text { Time of } \\
\text { MRI after } \\
\text { OLT } \\
\text { (days) }\end{array}$} & \multicolumn{3}{|c|}{ MRI features } & \multirow{2}{*}{$\begin{array}{l}\text { Pontine- } \\
\text { brain } \\
\text { stem } \\
\text { lesions }\end{array}$} & \multirow{2}{*}{$\begin{array}{l}\text { Extrapontine- } \\
\text { brain stem } \\
\text { lesions }\end{array}$} & \multirow[t]{2}{*}{ Outcomes } \\
\hline & & & & $\mathrm{T} 1$ & $\begin{array}{l}\text { T2/ } \\
\text { FLAIR }\end{array}$ & DWI & & & \\
\hline 17 & 3 & Coma & 36 & - & ++ & + & Yes & Yes & $\begin{array}{l}\text { Clinical improvement with residual } \\
\text { confusion } \\
\text { Discharge from hospital after } \\
4 \text { months } \\
\text { Persistent cerebellar syndrome } \\
\text { Alive and independent }\end{array}$ \\
\hline 18 & 4 & $\begin{array}{l}\text { Seizure, altered } \\
\text { consciousness }\end{array}$ & 25 & - & +++ & + & Yes & No & $\begin{array}{l}\text { Discharge from hospital after } 11 \\
\text { months, lived in a medical home } \\
\text { Persistent spastic tetraparesia, } \\
\text { cerebellar ataxia, severe dysarthria } \\
\text { Death at } 8 \text { years lung carcinoma }\end{array}$ \\
\hline 19 & 11 & $\begin{array}{l}\text { Aphasia, apraxia, } \\
\text { extrapyramidal } \\
\text { syndrome }\end{array}$ & 32 & - & +++ & - & No & Yes & $\begin{array}{l}\text { Discharge from hospital after } \\
3 \text { months } \\
\text { Persistent dysarthria } \\
\text { Death at } 7 \text { years colic carcinoma }\end{array}$ \\
\hline
\end{tabular}

Majority of patients show pontine and extrapontine lesions on T2/FLAIR

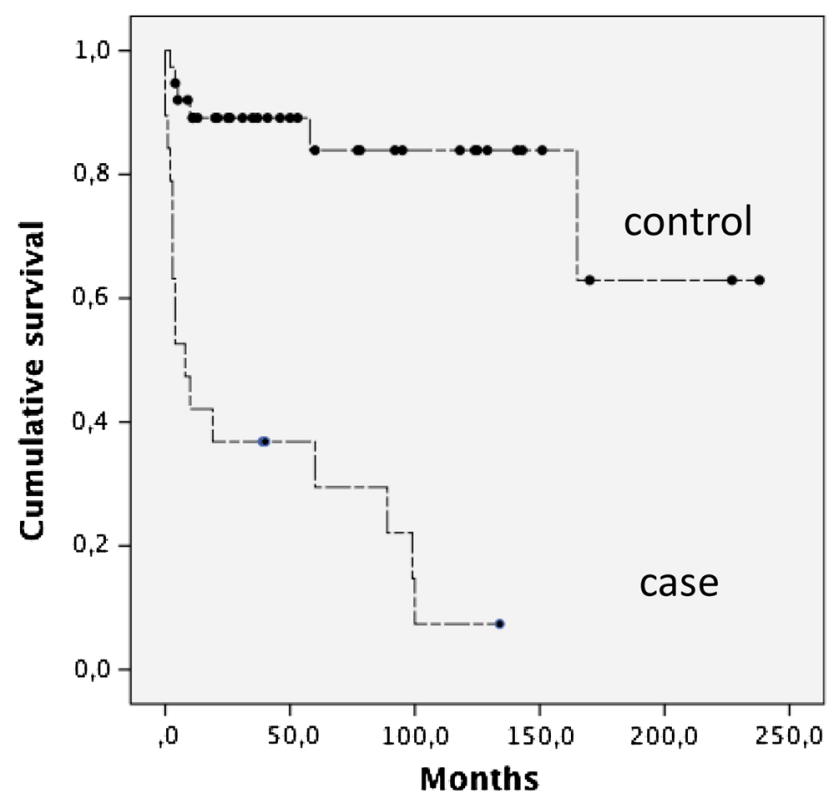

Fig. 1 Survival in the two groups, log-rank $p<0.001$

In the pre-operative clinical data we did not find any difference in terms of encephalopathy, ascites, and BMI. Indications for OLT were similar in both groups and, despite the fact that CPM has often been associated with alcohol consumption, this study shows that neurological complications could occur equally in patients with endstage liver diseases of any etiology.

Most of the patients with CPEPM had high MELD score (mean $26 \pm 2.2$, median 24, range 11-37) and were representative of the general population waiting for OLT; the decreased liver function was not by itself a risk factor to develop CPEPM as the controls had similar MELD score. Recently, Lee et al. [11] published the first and unique case-control study with cases of CPM and age-, gender-, and date of operation-matched controls. They suggested that the MELD-Na score, as indicator of severe end-stage cirrhosis, predicts the occurrence of CPM. As their patients were not matched for the MELD score, they concluded that patients with more severe liver dysfunction had higher risk to develop CPM. But, as shown in our study, the MELD score is not a strong predictor of CPEPM occurrence. Still the presence of more severe patients on the waiting list will potentially increase the incidence of CPEPM after liver transplantation.

We did not observe any association among CPEPM, the type of immunosuppression, and high CNI trough levels. Still, some reports incriminate CNI in the occurrence of CPEPM [42]. We cannot exclude that cyclosporine or tacrolimus played a role in our patients neurological deterioration. Nevertheless none of our patients with suspected CPEPM showed the classical but controversial lesions described in CNI toxicity, such as the posterior reversible encephalopathy syndrome or diffuse microangiopathy.

CPEPM was associated with a significantly higher mortality rate. Despite the fact that CPEPM was not the direct cause of every death, it probably increases the risk of pulmonary infections, sepsis, and multisystem failure. In addition, severe neurological symptoms probably changed the general way to take care of specific pathology such as $\mathrm{HCV}$ recurrence. 
Our study is the largest one published till date reporting patients who developed CPEPM after OLT and the second to be controlled. However, this work has several limitations. It is a retrospective analysis covering 22 years of our liver transplantation program and therefore lacking interesting data such as osmolality before and after OLT, fluctuation of serum sodium during surgery, total fluid infusion, etc.

Our patients were selected on a retrospective mode based on the development of suggestive neurological symptoms, confirmed by a typical image of demyelinisation on MRI. Controls had no MRI imaging and we cannot exclude subclinical CPEPM. Findings from autopsy series suggest that asymptomatic or mildly symptomatic CPEPM may be significantly more common than suspected in OLT patients. Therefore only a prospective study with pre- and post-transplant MRI and neurological follow-up will be able to determine the real incidence of CPEPM after OLT and the actual risk factors for this rare but potentially fatal complication. However, CPEPM is such a rare event after OLT that a prospective analysis would be difficult to obtain.

\section{Conclusion}

Our study shows that in high MELD score patients undergoing OLT, severe hyponatremia, massive perfusions of Na-rich products, post-operative hemorrhagic complications and important fluctuations of serum sodium are risk factors of developing CPEPM. The addition of more than two of these conditions is strongly predictive of CPEPM. This rare but potentially severe complication, albeit more frequent in case of severe hyponatremia, may concern patients with normal or near normal serum sodium concentration in presence of other risk factors. We can postulate that the incidence of CPEPM will increase in the future. Indeed, patients with higher MELD scores and consequently increased risk of surgery-related hemorrhagic complication, massive transfusion, or sodium shifts are now selected for OLT. Therefore, diuretic drugs should be used with caution before OLT in patient with hyponatremia, effective drugs against dilutional hyponatremia such as vaptan should be studied in this specific situation, careful monitoring of natremia in the perioperative period, and use of water-free perfusion in case of massive bloodproducts transfusion are critical points of this patient management.

Acknowledgments Christian Toso was supported by the Swiss National Science Foundation (SCORE Grant 3232230-126233).

Conflict of interest Isabelle Morard, Yvan Gasche, Mark Kneteman, Christian Toso, Ariane Mentha, Glenda Meeberg, Gilles
Mentha, Norman Kneteman, and Emiliano Giostra declare that they have no conflict of interest.

\section{References}

1. Adams RD, Victor M, Mancall EL. Central pontine myelinolysis: a hitherto undescribed disease occurring in alcoholic and malnourished patients. AMA Arch Neurol Psychiatry. 1959;81(2):154-72.

2. Wright DG, Laureno R, Victor M. Pontine and extrapontine myelinolysis. Brain. 1979;102:361-85.

3. Pfister HW, Einhaupl KM, Brandt T. Mild central pontine myelinolysis: a frequently undetected syndrome. Eur Arch Psychiatry Neurol Sci. 1985;235(3):134-9.

4. Kato T, Hattori H, Nagato M, et al. Subclinical central pontine myelinolysis following liver transplantation. Brain Dev. 2002;24(3):179-82.

5. Winnock S, Janvier G, Parmentier F, et al. Pontine myelinolysis following liver transplantation: a report of two cases. Transpl Int. 1993;6:26-8.

6. Fryer JP, Fortier M, Metrakos P, et al. Central Pontine Myelinolysis and Cyclosporine neurotoxicity following liver transplantation. Transplantation. 1996;61:658-61.

7. Bonham CA, Dominguez EA, Fukui MB, et al. Central nervous system lesions in liver transplant recipients: prospective assessment of indications for biopsy and implications for management. Transplantation. 1998;66(12):1596-604.

8. Bronster DJ, Emre S, Boccagni P, Sheiner PA, Schwartz ME, Miller CM. Central nervous system complications in liver transplant recipients-incidence, timing, and long-term follow-up. Clin Transplant. 2002;14:1-7.

9. Yu J, Shu-Sen Z, Ting-Bo L, Yan S, Wei-Lin W, Qing-Hong K. Possible causes of central pontine myelinolysis after liver transplantation. World J Gastroenterol. 2004;10(17):2540-3.

10. Kim BS, Lee SG, Hwang S, et al. Neurologic complications in adult living donor liver transplant recipients. Clin Transplant. 2007;21:544-7.

11. Lee EM, Kang JK, Yun SC, et al. Risk factors for central pontine and extrapontine myelinolysis following orthotopic liver transplantation. Eur Neurol. 2009;62(6):362-8.

12. Yun BC, Kim WR, Benson JT, et al. Impact of pretransplant hyponatremia on outcome following liver transplantation. Hepatology. 2009;49(5):1610-5.

13. Wszolek ZK, McComb RD, Pfeiffer RF, et al. Pontine and extrapontine myelinolysis following liver transplantation. Relationship to serum sodium. Transplantation. 1989;48(6): 1006-12.

14. Estol CJ, Faris AA, Martinez AJ, Ahdab-Barmada M. Central pontine myelinolysis after liver transplantation. Neurology. 1989;39:493-8.

15. Boon AP, Adams DH, Buckels JA, McMaster P. Neuropathological findings in autopsies after liver transplantation. Transplant Proc. 1991;23:1471-2.

16. Ferreiro JA, Robert MA, Townsend J, Vinters HV. Neuropathologic findings after liver transplantation. Acta Neuropathol. 1992;84(1):1-14.

17. Singh N, Yu VL, Gayowski T. Central nervous system lesions in adult liver transplant recipients: review with implications for management. Medicine. 1994;73:110-8.

18. Kleinschmidt-DeMasters BK, Rojiani AM, Filley CM. Central and extrapontine myelinolysis: then and now. J Neuropathol Exp Neurol. 2006;65:1-11.

19. Lampl C, Yazdi K. Central pontine myelinolysis. Eur Neurol. 2002;47(1):3-10. 
20. Cuervas-Mons V, Martinez AJ, Dekker A, Starzl TE, Thiel DH. Adult liver transplantation: an analysis of the early causes of death in 40 consecutive cases. Hepatology. 1986;6:495-501.

21. Adams DH, Gunson B, Honigsberger L, et al. Neurological complications following liver transplantation. Lancet. 1987;1:949-51.

22. Miller GM, Baker HL, Okazaki H, Whisnant JP. Central pontine myelinolysis and its imitators: MR findings. Radiology. 1988;168:795-802.

23. Reyes J, Gayowski T, Fung J, Todo S, Alessiani M, Starzl TE. Expressive dysphasia possibly related to FK 506 in two liver transplant recipients. Transplantation. 1990;50:1043-5.

24. Bird GL, Meadows J, Goka J, Polson R, Williams R. Cyclosporin-associated akinetic mutism and extrapyramidal syndrome after liver transplantation. J Neurol Neurosurg Psychiatry. 1990;53:1068-71.

25. Boon AP, Carey MP, Adams DH, Buckels J, McMaster P. Central pontine myelinolysis in liver transplantation. J Clin Pathol. 1991;44:909-14.

26. Burkhalter EL, Starzl TE, Van Thiel DH. Severe neurological complications following orthotopic liver transplantation in patients receiving FK 506 and Prednisone. J Hepatol. 1994;21:572-7.

27. Kabeer MH, Filo RS, Milgrom ML, et al. Central pontine myelinolysis following orthotopic liver transplant: association with cyclosporin toxicity. Postgrad Med J. 1995;71(834):239-41.

28. Menger H, Jorg J. Outcome of central pontine and extrapontine myelinolysis $(n=44)$. J Neurol. 1999;246:700-5.

29. Murdoch M, Chang M, McVicar J. Central pontine myelinolysis after liver transplantation: a case report. Transpl Int. 1995; 8(5):399-402.

30. Rodriguez J, Benito-Leon J, Molina JA, Ramos A, Bermeo F. Central Pontine myelinolysis associated with cyclosporine in liver transplantation. Neurologia. 1998;13:437-40.

31. Buis CI, Wijdicks EFM. Serial magnetic resonance imaging of central pontine myelinolysis. Liver Transplant. 2002;8:643-7.
32. Guo Y, Hu JH, Lin W, Zheng KH. Central pontine myelinolysis after liver transplantation: MR diffusion, spectroscopy and perfusion findings. Magn Reson Imaging. 2006;24:1395-8.

33. Senzolo M, Ferronato C, Burra P. Neurologic complications after solid organ transplantation. Transpl Int. 2009;22(3):269-78.

34. Bechstein WO. Neurotoxicity of calcineurin inhibitors: impact and clinical management. Transpl Int. 2000;13(5):313-26.

35. Howard SA, Barletta JA, Klufas RA, Saad A, De Girolami U. Best cases from the AFIP: osmotic demyelination syndrome. Radiographics. 2009;29:933-8.

36. Chu K, Kang DW, Ko SB, Kim M. Diffusion-weighted MR findings of central pontine and extrapontine myelinolysis. Acta Neurol Scand. 2001;104:385-8.

37. Kamath PS, Wiesner RH, Malinchoc M, et al. A model to predict survival in patients with end-stage liver disease. Hepatology. 2001;33:464-70.

38. Ashrafian H, Davey D. A review of the causes of central pontine myelinolysis: yet another apoptotic illness? Eur J Neurol. 2001;8:103-9.

39. Thurston JH, Hauhart RE, Nelson JS. Adaptive increases in amino acids (taurine in particular), creatine, and electrolytes prevent cerebral edema in chronically hyponatremic mice; rapid correction (experimental model of central pontine myelinolysis) causes dehydration and shrinkage of brain. Metab Brain Dis. 1987;2:223-41.

40. Brown WD. Osmotic demyelination disorders: central pontine and extrapontine myelinolysis. Curr Opin Neurol. 2000;13:6917.

41. Gines P, Guevara M. Hyponatremia in cirrhosis: pathogenesis, clinical significance, and management. Hepatology. 2008;48: 1002-10.

42. Fukazawa K, Nishida S, Aguina L, Pretto E Jr. Central pontine myelinolysis (CPM) associated with tacrolimus (FK506) after liver transplantation. Ann Transplant. 2011;16(3):139-42. 